ficulties with the return of the emperor and were well treated by the Derg who regarded them as part of the oppressed they claimed to support. Several major businessmen of Yemeni origin have thrived in Ethiopia and extended their operations internationally but the most successful are those who are part of the patronage networks of key political players in successive regimes.

In both Djibouti and Ethiopia, the war on terrorism has led to programmes to support what are regarded as good Islamic practices and to discourage the bad. Yemenis have found themselves on both sides, sometimes to the disadvantage of some long established families and individuals.

Dr. Bezabeh is an anthropologist and discusses the theoretical assumptions that have influenced the main scholars in their examination of diasporas and the Indian Ocean. He gives many examples of how individual Yemenis and families have coped with dramatic change in the politics of Djibouti and Ethiopia and in their Yemeni homeland. He cites a wealth of sources and provides much new information that will be invaluable to historians and students of the Yemeni diaspora. The book fills an important gap in our knowledge of the diaspora in the Yemeni neighbourhood so that this can be examined in the context of the richer sources on what might be called the far diaspora. He makes a compelling and elegantly argued case for his main thesis that it is the policies of states that most affect migration and migrant communities.

Djibouti with its flourishing port is a reminder of what the port of Aden might have become. Aden in 1960 was the second busiest port and over half its population were migrants from the Horn as well from all over Yemen. Today it is a pale shadow of its great past and is likely to remain a source of emigration for years to come as a result of the actions of states, political groups and terrorists.

Noel Brehony

London, United Kingdom

\title{
Arthur Shuster, Punishment and the History of Political Pbilosophy: From Classical Republicanism to the Crisis of Modern Criminal Justice (Toronto: University of Toronto Press, 2016). 180 pp. Hardback \$50.00.
}

This book announces an important ambition. Western society's institutions of punishment are in crisis; the technocratic empirical inquiries of value-free criminology are inadequate to address the problem; what is needed is a return to the basic normative, philosophical questions of what punishment is for and how it may justifiably be used; these questions, in turn, can only be properly appreciated and answered by understanding how responses to them have developed in the history of political philosophy. However, much as all of this seems exactly right, the present book unfortunately engages with this ambition only sporadically. The book selects a plausible range of figures from the history of political thought who have had something to 
say about punishment, and surveys themes in their work. But while there are occasional gestures towards the construction of a narrative that will help us understand how we have got to the impasse in which we currently find ourselves, the surveys of each figure are not sufficiently joined up to provide a coherent answer to this question.

The "Introduction" sets out three aspects of the crisis of contemporary criminal justice: mass incarceration; abuses of the rights of offenders; and continuing controversy over the justifiability of retribution (5-6). The latter is connected to the claim that "a truly satisfying theory of punishment-one that adequately addresses all of our basic moral concerns and questions - continues to elude contemporary punishment theory" (11). The main thesis of the book, then, is that "this crisis can best be understood in light of the momentous shift in the history of Western political thought from classical republicanism to modern individual natural right and contractarianism" (11).

Now each aspect of this assertion here is debatable-for instance, has contemporary punishment theory really not come up with a satisfying theory; was there really a deep shift from classical republicanism to a social contract approach in political life as opposed to political theory; can the criminal justice crisis be explained in terms of a failure in the history of ideas rather than as a result of the development of social forces or the rise of capitalism? - but at least the ambition announced is interesting and important. However, the book seems to lose interest in this overarching theme as it surveys some major aspects of ideas about punishment in five authors: Plato (the Laws); Hobbes; Montesquieu; Kant; and Foucault (in fact the supposedly overarching theme recurs in the discussion of Foucault, as it must do given the claims Foucault makes, but not in any sense that could be described as "tying everything together"). The book sometimes seems more concerned with giving an account of these authors' views on punishment for their own sake, rather than in the interest of developing an underlying argumentative strategy. That is, even if these authors are well chosen, the author does not define a clear set of questions that the study will investigate, and that will help to illuminate the crisis of punishment from the perspective of the history of political thought; and does not do enough work to show how the topics selected for discussion in each of these chapters inform the task of answering those questions.

A concern I had from the outset is that, while the author claims that there is an impasse in current normative theory about punishment, the only attempt to justify this refers to Rawls and Hart, theories that were developed in the 1950s. Maybe the author's verdict is correct, but it is not shown to be so by any argument in this book. A similar charge could be made against the author's discussions of the normative theories put forward by Plato, Hobbes, Kant, etc. A reader versed in normative political theory might find these discussions lacking in incisiveness, repeating as they do some of the main charges that might be laid against the theory in question, but doing little to consider potential alternative interpretations that might give 
more normatively compelling results.

Having said this, there are times when the author does seem to be on to something genuinely insightful. For instance, the chapter on Hobbes claims that, given Hobbes's contractarian starting points, and his view of the maintenance of security as the exclusive point of political society, the promotion of compliance with law (or the discouragement of lawful or dangerous behaviour), could be the only possible point of punishment. This seems right as an observation about the limits of a certain contractarian tradition; but someone who wanted to know whether this was decisive reason to reject the contractarian tradition, or indeed a decisive reason to accept it, will be disappointed by the discussion here. The author makes some standard observations about how a purely consequentialist approach would lead to unacceptable things like the punishment of the innocent and so on. However, no elaboration of the Hobbesian tradition to address these criticisms is considered.

The chapter on Kant has similar limitations. Here the discussion concerns whether Kant was really a retributivist, and the attempt is made to explain how charges made by Hill and Tunick to the effect that he was not can be answered. It is not really explained how this particular exegetical discussion is necessary to further the overarching theme of the book-beyond the claim that Kant represents a revival of retributivism within modern natural rights theory. But the author does point out, correctly, that there are a number of retributivist themes in Kant, including his discussion of conscience and of the highest good, and that is something that Hill and Tunick would have to answer. However, although this initial riposte is successful to that extent, there is no attempt to consider how Tunick and Hill might respond. After all, it can't be thought that they are unaware of the parts of Kant to which the author points. So don't they have reasons for thinking that, despite them, Kant is not a retributivist in his political philosophy?

It may be that the book is intended to be more historical than philosophical or normative. However, even here I have some doubts about the analysis presented in each chapter. Little attempt is made to contextualise each author in their historical period. Proponents of the Quentin Skinner approach to the history of political thought will not be impressed by what they find here. From this book one would have no idea of the Christian, Pietist, background to Kant's thought, for instance, but would rather get the impression that his retributivism was an attempt to rescue a persisting strong intuition from the attack on it launched by Hobbes. Except that there is also no attempt made to show that Kant had read Hobbes, or Montesquieu, or that there were causal links between any of these authors that would justify their selection. If they were selected because of the normative interest of what they say then, fine, the historical detail can be at least to some extent dispensed with. But as I say, the normative does not seem to be the main strength of this book, despite the claims announced at the outset.

Overall, this book seems like a missed opportunity. The project that it 
claims to undertake is one that someone really should work on (though more people have worked on it than one would be aware of from Shuster's discussions). Unfortunately, its promise is not followed through.

Christopher Bennett

University of Sheffield

\section{Carina E. Ray, Crossing the Color Line: Race, Sex, and the Contested Politics of Colonialism in Ghana (Athens: Ohio University Press, 2015). 364 pp. Pa- perback \$32.95.}

In the past few decades, our understanding of the place of race within Imperialism has greatly expanded. Yet oftentimes the place of individual relationships becomes lost in these larger conversations. Carina E. Ray addresses this deficiency in her intriguing and innovative study of the place of inter-racial relationships within colonial Ghana. Especially important here is that Ray explores all sides of this issue as she examines the place of relationships within Ghana from both an official imperial and a local perspective and then does the same thing for the Ghanaians who found themselves in England.

This well written and researched work continues our quest to understand the role that race played within colonial empires. Ray works to understand this by exploring how these relationships constructed, defined, and challenged empire. By doing so she brings a distinct human element into this history, thereby complicating it when we examine it upon a personal level. She accomplishes this through the effective utilization of individual case studies of specific inter-racial relationships and from this she carefully constructs her analysis. Her study illustrates the complexity of race within the British Empire, the issues that colonial officials had to deal with as they worked to impose their control upon the colonized peoples, how the colonized peoples reacted and adapted to the changes wrought by empire, and, finally, how similar situations in diverse parts of the empire were reacted to differently. Ray not only focuses upon the relationship between the metropole and the colony, but clearly shows how the people of the colony reacted to events within the metropole.

One important theme throughout the work concerns the place of "native marriages" within Ghana. Ghana has a long history of sustained interactions with Europeans, commencing with the 1482 construction of Elmina castle and lasting until the present. Thus, while the relationship between the peoples of the Gold Coast and Britain had radically changed during the period of this study, especially in regards to power and economics, the structures of cross-cultural relations were well-established. As Ray shows, the Akan had a long history of incorporating outsiders into their community and this was especially true during the period of Atlantic Trade. Along the Gold Coast, European traders and company officials, be they Dutch, British, French or Danish, entered into relationships with coastal women; 